REVIEW

\title{
Hyperinsulinaemia, hyperaminoacidaemia and post-exercise muscle anabolism: the search for the optimal recovery drink
}

\author{
A H Manninen
}

Dietary supplements and other ergogenic aids are popular among athletes. Recent studies have shown that nutritional mixtures containing protein hydrolysates, added leucine, and high-glycaemic carbohydrates greatly augment insulin secretion compared with high-glycaemic carbohydrates only. When post-exercise hyperinsulinaemia is supported by hyperaminoacidaemia induced by protein hydrolysate and leucine ingestion, net protein deposition in muscle should occur. Thus, consumption of post-exercise recovery drinks containing these nutrients in conjunction with appropriate resistance training may lead to increased skeletal muscle hypertrophy and strength. However, the long-term effects on body composition and exercise performance remain to be determined.

Correspondence to: Dr Manninen, Advanced Research Press, Inc, 690

Route 25A, Setauket, NY

11733, USA;

sportsnutrition@

luukku.com

Accepted 22 August 2006 Published Online First 1 September 2006
"The importance of nutrition following training-induced homeostatic disruption can be traced to our most ancient of writings. Esau, the first born of Isaac, in what is estimated to be 1800 BC appears to have had incredible genetics. His training sessions, however, were not found in the gym, but rather in the field as he hunted the most ferocious of beasts. So vital was the post-workout meal to the father of the Edomites that he sold his birthright to his brother Jacob for it! ${ }^{\prime \prime 1}$

Appropriate resistance exercise leads to significant skeletal muscle hypertrophy, which can occur through an increase in protein synthesis, a decrease in protein degradation, or both. Although stimulation-that is, resistance exercise-is important for muscle hypertrophy, nutrient availability appears to be a critical factor regulating the degree of hypertrophy. Obviously, the hormonal milieu of the muscle also has a major impact on protein synthesis.

It is now apparent that both increased insulin and increased availability of amino acids are important for maximizing muscle protein anabolism. If hyperinsulinaemia is not supported by an exogenous amino acid supply, plasma as well as muscle free amino acid concentrations fall because of reduced splanchnic release. ${ }^{2}$ On the other hand, if amino acid concentrations are maintained at normal or higher concentrations, net protein deposition in muscle will occur because of stimulation of synthesis and possibly because of a simultaneous decrease in breakdown. ${ }^{2}$

The importance of amino acid availability for the stimulatory effects of insulin to be evident was highlighted by Bennet et al, ${ }^{3}$ who reported that insulin, given with sufficient amino acids, can stimulate leg and whole body protein balance by mechanisms including stimulation of protein synthesis and inhibition of protein breakdown. This is in line with the recent data obtained by Borsheim et al, ${ }^{4}$ who showed that protein balance over the muscle remains negative after resistance exercise when only carbohydrate (CHO) is ingested. In sharp contrast, amino acid ingestion alone significantly increases muscle protein anabolism after resistance exercise. ${ }^{5}$ However, consumption of both amino acids and $\mathrm{CHO}$ results in much greater effects on muscle protein anabolism, ${ }^{6}$ suggesting an interactive effect between insulin, amino acid availability, and resistance exercise. Also, it is well established that the stimulatory effect of amino acids on muscle protein synthesis is greater after exercise than at rest. ${ }^{7}$ Thus, nutrient timing is also an important consideration. ${ }^{8-11}$

Given the fact that raising the plasma insulin concentration is key to stimulating muscle protein synthesis and limiting protein catabolism after exercise, ${ }^{12}$ it is not surprising that some athletes abuse insulin to increase skeletal muscle hypertrophy. Insulin injections reportedly can produce "rapid and noticeable [muscle] growth... almost immediately after starting insulin therapy" ${ }^{13}$ Most athletes choose to administer insulin immediately after a workout $^{13}$; they apparently realise that it is the most anabolic time to use this hormone. However, insulin abuse is extremely risky-one mistake in dose or diet can be fatal. Fortunately, recent studies have focused on safe insulinotropic nutritional mixtures containing protein hydrolysates, certain added amino acids (especially leucine), and high-glycaemic $\mathrm{CHO}$-for example, dextrose and maltodextrine. ${ }^{14-18}$

In this review, I propose that post-exercise hyperinsulinaemia supported by protein hydrolysate and leucine ingestion-induced hyperaminoacidaemia increases net protein deposition in muscle, leading to increased skeletal muscle hypertrophy and strength, when combined with appropriate resistance training. Firstly, this review

Abbreviations: $\mathrm{CHO}$, carbohydrate; IGF-I, insulin-like growth factor I 
provides some information on (1) amino acid-stimulated insulin secretion, (2) the effects of leucine on post-exercise muscle protein synthesis, and (3) protein hydrolysates. Then studies examining the effects of insulinotropic nutritional mixtures on insulin secretion, nitrogen utilisation, and postexercise muscle protein anabolism are reviewed. Finally, the effects of post-exercise hyperinsulinaemia on fat oxidation and de novo lipogenesis are discussed.

\section{AMINO ACID-STIMULATED INSULIN SECRETION}

Formerly, it was believed that insulin secretion was controlled almost entirely by blood glucose concentration. However, it later become apparent that amino acids also play a very important role in controlling insulin secretion. Certain amino acids cause insulin release in humans even under conditions where the blood sugar changes little from its basal level. ${ }^{19}$ However, changes in blood sugar concentrations markedly influence the responsiveness of beta cells to individual amino acids. Studies on isolated perfused rat pancreas and islets have shown that physiological amino acid mixtures and even pharmacological concentrations of individual amino acids require the presence of permissive concentrations of glucose $(2.5-5.0 \mathrm{mM})$ to be effective beta cell stimulants. ${ }^{19}$ However, leucine is an exception. ${ }^{20}$ Contrary to popular belief, oral arginine is not an effective insulin secretagogue. ${ }^{14}$

\section{EFFECTS OF LEUCINE ON POST-EXERCISE MUSCLE PROTEIN SYNTHESIS}

The key branched-chain amino acid leucine acts as a nutrient signal to stimulate muscle protein anabolism. Leucine affects muscle protein metabolism by decreasing the rate of protein degradation, ${ }^{21}$ probably by increasing circulating insulin. In addition, leucine affects phosphorylation of key proteins involved in the regulation of protein synthesis, which has been shown to occur even in the absence of an increase in circulating insulin. ${ }^{22}$ After exercise, recovery of muscle protein synthesis requires dietary protein or branched-chain amino acids to increase tissue concentrations of leucine. ${ }^{23}$ The important bottom line is that insulin and leucine allow skeletal muscle to coordinate protein synthesis with physiological state and dietary intake. ${ }^{23}$ For more detailed reviews, see the recent papers by Norton and Layman, ${ }^{23}$ Blomstrand et $a^{24}$ and Garlick.25

\section{PROTEIN HYDROLYSATES}

Protein hydrolysates are produced from purified protein sources by heating with acid or, preferably, addition of proteolytic enzymes, followed by purification procedures. ${ }^{26}$ Extreme bitterness is a negative attribute of most protein hydrolysates. Fortunately, specific "debittering" strategies have focused on the application of proline-specific exopeptidases and endopeptidases given the contribution of proline residues to hydrolysate bitterness. ${ }^{27}$ The hydrolytic process mimics our own digestive actions; thus some feel it is an ideal way to process dietary protein. Extensively hydrolysed proteins containing mostly dipeptides and tripeptides are absorbed more rapidly than free-form amino acids and much more rapidly than intact (non-hydrolysed) proteins. ${ }^{26} 2829$ The considerably greater absorption rate of amino acids from dipeptides and tripeptides than from an amino acid mixture appears to be the result of uptake by a system that has a greater transport capacity than the amino acid carrier system, thus minimising competition between its substrates. ${ }^{28}$ Each protein hydrolysate is a complex mixture of peptides of different chain length together with free amino acids, which can be defined by a global value known as degree of hydrolysis, which is the fraction of peptide bonds that have been cleaved in the starter protein. ${ }^{30}$ However, two protein hydrolysates made by different methods-for example, oligopeptides/significant free amino acids versus mainly dipeptides and tripeptides-may have a similar degree of hydrolysis even though their absorption kinetics are probably quite different. ${ }^{31}$ Consequently, it has been suggested that it is better to use the term "peptide chain length profile". ${ }^{31}$

It seems that only dipeptides and tripeptides, which remain after luminal and brush-border peptidase digestion, are absorbed intact. ${ }^{32}$ Tetrapeptides and higher peptides appear to require prior brush-border hydrolysis before their hydrolysis products can be absorbed. ${ }^{32}$ Although the starter protein and method of hydrolysis affect absorptive characteristics, the peptide chain length is the most important variable. Protein hydrolysates produced from various sources showed increased amino acid absorption in humans when the proportion of dipeptides and tripeptides was increased. ${ }^{32}$ Thus, to maximise absorption rate, the ideal protein hydrolysate should contain mainly dipeptides and tripeptides. Such a protein hydrolysate seems to produce the most immediate hyperaminoacidaemia. In general, it is the kinetics of the absorption (rather than the net absorption of amino acids) that determines the greater nutritional value of the protein hydrolysates. The use of a protein hydrolysate in postexercise drinks is preferred because it results in a faster increase in plasma amino acid concentrations during a $2 \mathrm{~h}$ period than does intact protein, ${ }^{14}$ and in turn the concentrations of essential amino acids in the blood regulate muscle protein synthesis. ${ }^{33}$ A practical advantage is that one can ingest a protein hydrolysate-containing supplement immediately after exercise without becoming bloated and not excessively suppressing appetite, so one can eat another meal sooner, possibly optimising the post-exercise "anabolic window". In addition, protein hydrolysate ingestion has a strong insulinotropic effect. ${ }^{14-18}$

Clearly, hydrolysed whey protein is the most popular protein hydrolysate among athletes. Whey protein has been singled out as the ultimate source of protein on the basis of an excellent amino acid profile. ${ }^{26}{ }^{34}$ Whey may offer other benefits too. ${ }^{34-39}$ Casein hydrolysate is also used in some commercial protein mixtures. It should be realised that the biological value of hydrolysed collagen (also known as gelatin) is zero; thus, collagen supplementation as a protein source is not recommended. However, it has been suggested that hydrolysed collagen may be useful in counteracting degenerative joint diseases. ${ }^{40} 41$ Finally, some commercial products are enriched with wheat gluten hydrolysate-that is, "glutamine peptides". Wheat gluten has a unique amino acid profile: glutamine residues account for about $40 \%$ of the amino acids. ${ }^{42}$ Glutamine is an important fuel for some cells of the immune system and may have specific immunostimulatory effects. ${ }^{43}$

It is worth noting that the "classical" model of protein metabolism, which views nitrogen intake in terms of the flux of free amino acids from dietary protein and their exchange between plasma and intracellular compartments and between free and protein-bound amino acids, is misleading because it ignores the flux of amino acids through intermediate pools of small peptides. ${ }^{32}$

\section{EFFECTS OF INSULINOTROPIC NUTRITIONAL MIXTURES ON INSULIN SECRETION AND NITROGEN UTILISATION}

A study by Calbet and MacLean ${ }^{44}$ was implemented to determine the effects of different protein-containing solutions on insulin response and amino acid availability in healthy humans. Four different $600 \mathrm{ml}$ solutions were used. The glucose solution (control) contained only glucose (25 g/l), and the three additional solutions contained the same quantity of glucose plus protein $(0.25 \mathrm{~g} / \mathrm{kg}$ body mass $)$ but proteins were 
derived from different sources: whey hydrolysate, pea hydrolysate, and a complete cow's milk solution. This study indicated that:

(1) Ingestion of glucose and protein hydrolysate results in a synergistic and fast increase in plasma insulin. In fact, protein hydrolysates stimulated an increase in plasma insulin that was two and four times greater than that produced by the intact milk protein solution and glucose solution, respectively.

(2) Protein hydrolysates are absorbed at a faster rate from the small intestine than are intact milk proteins, as reflected by the rapid increase in the plasma concentration of branched-chain amino acids in peripheral blood.

(3) Whey protein hydrolysate elicited the greatest availability of amino acids during the $3 \mathrm{~h}$ postprandial period. The authors attributed this difference to the rapid increase in plasma amino acids evoked during the first $40 \mathrm{~min}$ of the digestive period, during which the increase was about $37 \%$ greater after the ingestion of whey protein hydrolysate solution than that after ingestion of the intact milk protein solution.

It is likely that the high concentrations of plasma amino acids and increased insulin explains the superiority of protein hydrolysates over intact proteins in promoting nitrogen utilisation. The co-ingestion of carbohydrate appears to affect the absorption kinetics, as one study showed that whey and casein proteins and their respective hydrolysates administered alone produce similar rates of intestinal absorption of amino acids. ${ }^{45}$ Alternatively, it is possible that this study used protein hydrolysates containing mainly oligopeptides.

More recently, Kaastra et al ${ }^{17}$ determined the extent to which the combined ingestion of high-glycaemic $\mathrm{CHO}$ and a casein protein hydrolysate with or without additional free leucine can increase insulin concentrations during postexercise recovery. Fourteen male athletes were participated in three randomised crossover trials in which they performed $2 \mathrm{~h}$ of exercise. Thereafter, the subjects were studied for $3.5 \mathrm{~h}$ during which they ingested $\mathrm{CHO}$ only $(0.8 \mathrm{~g} / \mathrm{kg} / \mathrm{h}), \mathrm{CHO}+$ protein hydrolysate $(0.8$ and $0.4 \mathrm{~g} / \mathrm{kg} / \mathrm{h}$, respectively), or $\mathrm{CHO}$ + protein hydrolysate + free leucine $(0.8,0.4$, and $0.1 \mathrm{~g} / \mathrm{kg} / \mathrm{h}$, respectively) in a double-blind fashion. The results revealed that plasma insulin responses were $108 \%$ and $190 \%$ greater in the $\mathrm{CHO}+$ protein hydrolysate and $\mathrm{CHO}+$ protein hydrolysate + leucine trial, respectively, compared with the $\mathrm{CHO}$ only trial. This study also indicated that addition of free phenylalanine, as applied in earlier studies, ${ }^{15}{ }^{16}$ is not necessary to obtain such high post-exercise insulin responses.

Similarly, Manders et $a l^{18}$ examined plasma insulin responses after co-ingestion of casein protein hydrolysate with and without additional free leucine with a single bolus of high-glycaemic CHO. Again, the subjects participated in three trials in which blood insulin responses were determined after the ingestion of beverages of different composition: CHO only $(0.7 \mathrm{~g} / \mathrm{kg}), \mathrm{CHO}+$ protein hydrolysate $(0.7$ and $0.3 \mathrm{~g} / \mathrm{kg}$, respectively) or $\mathrm{CHO}+$ protein hydrolysate + free leucine $(0.7,0.3$ and $0.1 \mathrm{~g} / \mathrm{kg}$, respectively). The result indicated that plasma insulin responses were $66 \%$ and $221 \%$ greater in the healthy subjects in the $\mathrm{CHO}+$ protein hydrolysate and $\mathrm{CHO}+$ protein hydrolysate + free leucine trials, respectively, compared with those in the $\mathrm{CHO}$ only trial. In other words, this study also showed that co-ingestion of a protein hydrolysate with additional leucine strongly augments insulin secretion after the consumption of a single bolus of $\mathrm{CHO}$.

This is in line with the data of Calbet and Holst, ${ }^{45}$ who reported that whey and casein hydrolysates elicited about $50 \%$ more gastric secretion than intact protein solutions, which was accompanied by higher plasma concentrations of glucose-dependent insulinotropic polypeptide during the first $20 \mathrm{~min}$ of the gastric emptying process. Besides well-known effects on pancreatic beta cells, this polypeptide also has direct metabolic effects on other tissues and organs, such as muscle, liver and adipose tissue, with most of its functions tending to increase anabolism.

The notion that the protein hydrolysates have strong insulinotropic properties is also supported by the studies examining the effects of intact protein-containing postexercise drinks. Ivy et $a l^{46}$ compared the effects of $\mathrm{CHO}+$ intact protein ( $80 \mathrm{~g} \mathrm{CHO}, 28 \mathrm{~g}$ protein, $6 \mathrm{~g}$ fat), low-CHO ( 80 $\mathrm{g} \mathrm{CHO}, 6 \mathrm{~g}$ fat), or high-CHO (108 g CHO, $6 \mathrm{~g}$ fat) and reported that plasma insulin concentrations did not differ at any time among treatments. However, Zawadzki et $a l^{47}$ observed that plasma insulin concentrations for the $\mathrm{CHO}+$ intact protein treatment (112 and $40.7 \mathrm{~g}$, respectively) were somewhat higher than those for the CHO treatment $(112 \mathrm{~g}$ $\mathrm{CHO}$ ).

A post-exercise drink containing a mixture of free amino acids also has a potent effect on insulin secretion. ${ }^{6}$ However, a large dose of amino acids can cause gastrointestinal discomfort. This may have something to do with the drink's osmolarity. A protein hydrolysate containing dipeptides and tripeptides reduces osmolarity because equal solution weights of dipeptides and tripeptides have the same and one-third the osmolarity of free amino acids, respectively. ${ }^{32}$

\section{EFFECTS OF INSULINOTROPIC NUTRITIONAL MIXTURES ON POST-EXERCISE MUSCLE ANABOLISM}

A sophisticated study by Koopman et al ${ }^{16}$ investigated postexercise muscle protein synthesis and whole body protein balance after the combined ingestion of high-glycaemic $\mathrm{CHO}$ with or without whey protein hydrolysate and/or leucine. Their nutritional protocol was rather rigorous; the subjects received a beverage volume of $3 \mathrm{ml} / \mathrm{kg}$ every $30 \mathrm{~min}$ to ensure a given dose of $0.3 \mathrm{~g}$ high-glycaemic $\mathrm{CHO} / \mathrm{kg}$ and $0.2 \mathrm{~g}$ of a protein hydrolysate $/ \mathrm{kg}$ every hour, with or without the addition of $0.1 \mathrm{~g} / \mathrm{kg} / \mathrm{h}$ free leucine. Repeated boluses were taken every 30 min until $330 \mathrm{~min}$ after exercise. The results revealed that the rates of whole body protein synthesis were highest in the $\mathrm{CHO}+$ protein hydrolysate + leucine trial: 95.6 $(0.1) \% v 92.0(0.4) \%$ and $94.2(0.4) \%$ in the $\mathrm{CHO}$ and $\mathrm{CHO}+$ protein hydrolysate trials, respectively. Similarly, the fractional synthetic rate in the vastus lateralis muscle was significantly higher in the $\mathrm{CHO}+$ protein hydrolysate + leucine trial than the CHO trial $(0.095(0.006) \% / \mathrm{h} v 0.061$ $(0.008) \% / h$, respectively), with intermediate values observed in the $\mathrm{CHO}+$ protein hydrolysate trial $(0.0820(0.0104) \% / \mathrm{h})$.

Furthermore, the investigators found plasma insulin responses to correlate negatively with whole body protein degradation, whereas whole body protein synthesis correlated positively with plasma insulin response. However, the fractional synthetic rate did not correlate with the plasma insulin response, whereas the mixed muscle protein fractional synthetic rate did correlate with the amount of leucine that was ingested. It is difficult to interpret these results given the massive supplementation. Nevertheless, the authors concluded that, "the additional ingestion of free leucine in combination with protein and carbohydrate likely represents an effective strategy to increase muscle anabolism following resistance exercise." Other recent studies have shown that relatively small doses of leucine can improve exercise performance ${ }^{48}$ and enhance the acquisition of strength. ${ }^{49}$

Although the Koopman study indicates that dietary supplementation-induced post-exercise hyperinsulinaemia plus hyperaminoacidaemia can have favourable effects on 
the acute phase response to resistance training, the effects of repeated supplementation on long-term adaptations to resistance training are currently unclear. To shed some light on this issue, Bird et al ${ }^{50}$ examined the effects of chronic highglycaemic $\mathrm{CHO}$ and/or essential amino acid supplementation on hormonal and muscular adaptations in untrained young men. All subjects followed the same supervised, resistance training protocol twice a week for 12 weeks. After resistance exercise, the subjects consumed a high-glycaemic $\mathrm{CHO}$ supplement, an essential amino acid (6 g) supplement, a combined high-glycaemic $\mathrm{CHO}+$ essential amino acid supplement, or a placebo containing only aspartame and citrus flavouring. The results revealed that $\mathrm{CHO}+$ essential amino acid supplementation enhances muscular and hormonal adaptations to a greater extent than either $\mathrm{CHO}$ or essential amino acids consumed independently. Specifically, ingestion of $\mathrm{CHO}+$ essential amino acids produced the greatest relative increase in type I muscle fibre cross-sectional area. Changes in type II muscle fibres exhibited a similar trend.

Although beyond the scope of this paper, it is very likely that chronic reductions in the exercise-induced cortisol response associated with post-exercise ingestion of $\mathrm{CHO}$ and amino acids also positively affect the skeletal muscle hypertrophic adaptation to resistance training through reductions in hormone-mediated protein degradation. For reviews, see the recent papers by Volek, ${ }^{51}$ Kraemer and Ratamess, ${ }^{52}$ and Crewther et al..$^{53}$

\section{YOU CAN HAVE YOUR PROTEIN SHAKE AND DRINK IT TOO}

Contrary to popular belief, higher protein intake has no adverse effects on healthy kidneys, ${ }^{54}{ }^{55}$ fluid status, ${ }^{56}$ or bone. ${ }^{57-60}$ In fact, proteins appear to have positive effects on bone health, as they increase circulating insulin-like growth factor I (IGF-I), which plays an important role in bone formation. ${ }^{58}$ For example, Ballard et $a l^{60}$ reported that a protein supplement during a strength and conditioning programme led to an increase in plasma concentrations of IGF-I in those subjects compared with the concentrations in a group who also trained but consumed an isocaloric $\mathrm{CHO}$ supplement. Also, serum bone alkaline phosphatase concentrations increased over time and tended to be higher in the protein group than in the $\mathrm{CHO}$ group, indicating increased bone formation.

In addition, IGF-I plays a critical role in development, growth, repair, and maintenance of skeletal muscle. ${ }^{61}$ Thus, it may partially explain why many strength/power athletes (especially bodybuilders) feel that a very high protein intake is beneficial for skeletal muscle hypertrophy. Indeed, studies indicate increased positive nitrogen balance when protein intake is increased ${ }^{62}$; however, more research is clearly needed before the mystery of protein requirements in those attempting to increase muscle mass is settled. ${ }^{62-65}$ Traditionally, the term "protein requirement" has meant the amount of dietary protein that must be consumed to provide the amino acids needed for the synthesis of those proteins irreversibly catabolised in the course of the body's metabolism. It should be noted, however, that strength/ power athletes are not concerned with the minimum amount of protein necessary to sustain normal body functions, but, rather, their absolute gains in muscle mass and strength. Other potential benefits of higher protein intake should be considered too. ${ }^{66-70}$

Interestingly, a recent placebo-controlled study by Flakoll et $a l^{71}$ reported that post-exercise protein/CHO supplementation (1) reduces bacterial/viral infections, (2) decreases the number of medical visits for muscle or joint problems, (3) diminishes episodes of heat exhaustion, (4) reduces muscle soreness, and (5) improves rifle scores in US marine recruits during basic training.

\section{EFFECTS OF POST-EXERCISE HYPERINSULINAEMIA} ON FAT OXIDATION AND DE NOVO LIPOGENESIS

The chief lipid-related functions of insulin are inhibition of lipolysis and lipid oxidation (at 13 and $44 \mu \mathrm{U} / \mathrm{ml}$, respectively). ${ }^{72}$ When insulin concentration falls below $13 \mu \mathrm{U} / \mathrm{ml}$, lipolysis is powerfully and exponentially stimulated. ${ }^{72}$ Volek et $a l^{73}$ reported that a very-low-CHO diet significantly decreased serum insulin $(-34 \%)$ and that about $70 \%$ of the variability in fat loss was accounted for by the decrease in serum insulin concentrations. Further, exogenous insulin promotes body fat accumulation, ${ }^{74}$ so one could speculate that insulinotropic supplements have similar effects. However, I feel this is hardly a concern for healthy athletes when these supplements are ingested immediately after rigorous exercise when the muscle cells are highly receptive to insulin ${ }^{75}$ and "screaming" for new fuel. The physiological state of a sedentary person and that of a well-trained athlete after exercise are poles apart. AMP-activated protein kinase acts as a "metabolic switch" in multiple tissues after exercise; the net effect of its activation is to increase fatty acid oxidation and diminish glycerolipid synthesis. ${ }^{76}$

To investigate the hormonal and metabolic adaptations occurring when high-glycaemic CHOs are ingested after exercise, Krzentowski et $\mathrm{l}^{77}$ compared the fate of a $100 \mathrm{~g}$ oral glucose load in healthy volunteers after an overnight fast at rest either without previous exercise or after $3 \mathrm{~h}$ of exercise performed on a treadmill at about $50 \%$ of the individual $\mathrm{VO}_{2} \mathrm{MAX}$. Indirect calorimetry indicated that glucose ingestion in post-exercise recovery was associated with decreased CHO oxidation and increased lipid oxidation when compared with control conditions. More recently, Folch et al ${ }^{78}$ reported that de novo lipogenesis was totally suppressed after exercise, even when a very large CHO load was ingested, and that fat oxidation remained high in subjects who had exercised after both the small and large CHO meal. Finally, Bird et al ${ }^{50}$ observed that post-exercise ingestion of high-glycaemic $\mathrm{CHO}$ did not inhibit resistance training-induced fat loss.

Certainly, this author is not suggesting that insulinotropic supplements should be used while watching TV. It is possible that the hyperinsulinaemic condition prevalent in obese, insulin-resistant individuals is responsible for the repartitioning of fatty acids away from oxidation and toward storage. ${ }^{79}$

\section{ANTI-INFLAMMATORY EFFECTS OF INSULIN}

Recently, Dandona et $a l^{80}$ proposed that insulin is the ideal anti-inflammatory agent for critically ill patients, because it normalises plasma glucose concentrations (glucose is proinflammatory) while exerting its anti-inflammatory effect. In addition, insulin suppresses generation of reactive oxygen species and the expression of $\mathrm{p} 47^{\text {phox }}$, a key component of NADPH oxidase, the enzyme that generates the superoxide radical. $^{80}$ Thus, insulin has antioxidant effects too. As strenuous exercise produces muscle inflammation ${ }^{81}$ as well as increases generation of reactive oxygen species, ${ }^{82}$ it is possible that post-exercise hyperinsulinaemia offers additional benefits beyond muscle protein synthesis.

\section{CONCLUSIONS}

The studies reviewed here indicate that nutritional mixtures containing protein hydrolysates, added leucine, and highglycaemic CHO greatly augment insulin secretion compared with high-glycaemic CHO only. When post-exercise hyperinsulinaemia is supported by protein hydrolysate and leucine ingestion-induced hyperaminoacidaemia, net protein deposition in muscle should occur. Thus, post-exercise recovery 


\section{What is already know on this topic}

- Both increased insulin and increased availability of amino acids are important for maximising muscle protein anabolism

\section{What this study adds}

- This paper proposes that post-exercise hyperinsulinaemia supported by hyperaminoacidaemia induced by protein hydrolysate and leucine ingestion increases net protein deposition in muscle, leading to increased skeletal muscle hypertrophy and strength, when combined with appropriate resistance training

drinks containing these nutrients in conjunction with appropriate resistance training may lead to increased skeletal muscle hypertrophy and strength. If so, such post-exercise supplements would be of considerable benefit not only to athletes but also to anyone who has lost muscle function through disease-for example, Duchenne muscular dystrophy. Future studies should evaluate their long-term effects on body composition and exercise performance.

\section{Authors' affiliations}

A H Manninen, Advanced Research Press, Inc, Setauket, NY, USA

Competing interests: The author is a consultant to BioQuest Pharmaceuticals, Inc.

\section{REFERENCES}

1 Wilson J. Acute \& chronic endocrine responses to exercise induced disruptions in homeostasis. Part one. Exercise endocrinology principles and catecholamines. HYPERplasia The Magazine. http:// www.abcbodybuilding.com/magazine03/exerciseendocronology $1 . \mathrm{htm}$ (accessed 7 Sep 2006).

2 Wolfe RR. Volpi E. Insulin and protein metabolism. In: Jefferson LS, Cherrington $A D$, eds. The endocrine pancreas and regulation of metabolism New York, Oxford University Press, 2001:735-57.

3 Bennet WM, Connacher AA, Scrimgeour CM, et al. Euglycemic hyperinsulinemia augments amino acid uptake by human leg tissues during hyperaminoacidemia. Am J Physiol 1990;259:E185-94.

4 Borsheim E, Cree MG, Tipton KD, et al. Effect of carbohydrate intake on net muscle protein synthesis during recovery from resistance exercise. J Appl Physiol 2004;96:674-8.

5 Tipton KD, Ferrando AA, Phillips SM, et al. Postexercise net protein synthesis in human muscle from orally administered amino acids. Am J Physiol 1999;276:E628-34.

6 Rasmussen BB, Tipton KD, Miller SL, et al. An oral essential amino acidcarbohydrate supplement enhances muscle protein anabolism after resistance exercise. J Appl Physiol 2000;88:386-92.

7 Wolfe RR. Protein supplements and exercise. Am J Clin Nutr 2000;72:551S-7S

8 Lemon PW, Berardi JM, Noreen EE. The role of protein and amino acid supplements in the athlete's diet: does type or timing of ingestion matter? Curr Sports Med Rep 2002;1:214-21.

9 Ivy J, Portman R. Nutrient timing: the future of sports nutrition. North Bergen, NJ: Basic Health Publications, 2004.

10 Levenhagen DK, Gresham JD, Carlson MG, et al. Postexercise nutrient intake timing in humans is critical to recovery of leg glucose and protein homeostasis. Am J Physiol Endocrinol Metab 2001;280:E982-93.

11 Fielding RA, Parkington J. What are the dietary protein requirements of physically active individuals? New evidence on the effects of exercise on protein utilization during post-exercise recovery. Nutr Clin Care 2002;5:191-6.

12 Ivy JL. Regulation of muscle glycogen repletion, muscle protein synthesis and repair following exercise. J Sports Sci Medicine 2004;3:131-8.

13 Llewellyn W. Anabolics 2002: anabolic steroids reference manual. Patchogue, NY: Molecular Nutrition, 2002.

14 van Loon $\mathrm{L}$, Saris WHM, Verhagen $\mathrm{H}$, et al. Plasma insulin responses after ingestion of different amino acid or protein mixtures with carbohydrate. Am J Clin Nutr 2000;72:96-105.
15 van Loon $\mathrm{L}$, Kruijshoop $M$, Verhagen $\mathrm{H}$, et al. Ingestion of protein hydrolysate and amino acid-carbohydrate mixtures increases postexercise plasma insulin responses in men. J Nutr 2000;130:2508-13.

16 Koopman R, Wagenmakers AJ, Manders RJ, et al. Combined ingestion of protein and free leucine with carbohydrate increases postexercise muscle protein synthesis in vivo in male subjects. Am J Physiol Endocrinol Metab 2005;288:E645-53.

17 Kaastra B, Manders RJ, van Breda E, et al. Effects of increasing insulin secretion on acute postexercise blood glucose disposal. Med Sci Sports Exerc 2006;38:268-75.

18 Manders RJ, Koopman R, Sluijsmans WE, et al. Co-ingestion of a protein hydrolysate with or without additional leucine effectively reduces postprandial blood glucose excursions in Type 2 diabetic men. J Nutr 2006;136:1294-9.

19 Newgard CB, Matschinksy FM. Substrate control of insulin release. In: Jefferson LS, Cherrington AD, eds. The endocrine pancreas and regulation of metabolism. New York: Oxford University Press, 2001:125-51.

20 Matschinsky FM, Ellerman J, Stillings S, et al. Hexones and insulin secretion. In: Hasselblatt A, Bruchhausen FV, eds. Handbook of experimental pharmacology. Berlin: Springer-Verlag, 1975:79-114.

21 Nair KS, Schwartz RG, Welle S. Leucine as a regulator of whole body and skeletal muscle protein metabolism in humans. Am J Physiol Endocrinol Metab 1992;263:E928-34.

22 Karlsson HK, Nilsson PA, Nilsson J, et al. Branched-chain amino acids increase $\mathrm{p} 70^{S 6 \mathrm{~K}}$ phosphorylation in human skeletal muscle after resistance exercise. Am J Physiol Endocrinol Metab 2004;287:E1-7.

23 Norton LE, Layman DK. Leucine regulates translation initiation of protein synthesis in skeletal muscle after exercise. J Nutr 2006;136:533S-537S.

24 Blomstrand E, Eliasson J, Karlsson HK, et al. Branched-chain amino acids activate key enzymes in protein synthesis after physical exercise. J Nutr 2006;136:269S-73S.

25 Garlick PJ. The role of leucine in the regulation of protein metabolism. J Nutr 2005; 135: 1553S-6S

26 Bucci LR, Unlu L. Protein and amino acid supplements in exercise and sport. In: Wolinsky I, Driskell JA, eds. Energy-yielding macronutrients and energy metabolism in sports nutrition. Boca Raton, FL: CRC Press, 2000:191-212.

27 FitzGerald RJ, O'Cuinn G. Enzymatic debittering of food protein hydrolysates. Biotechnol Adv 2006:24:234-7.

28 Pasquale MG. Protein foods vs. protein and amino acid supplements. In: Amino acids and proteins for the athlete: the anabolic edge. Boca Raton, FL: CRC Press, 1997:89-98.

29 Manninen AH. Protein hydrolysates in sports and exercise: a brief review. J Sports Med Sci 2004;3:60-63.

30 Adler-Nissen I. Enzymatic hydrolysis of food proteins. London: Elsevier, 1986.

31 Grimble GK. Mechanisms of peptide and amino acid transport and their regulation. In: Furst $P$, Young V, eds. Proteins, peptides and amino acids in enteral nutrition. Basel: Karger and Nestec, 2000:63-88.

32 Grimble GK. The significance of peptides in clinical nutrition. Ann Rev Nutr 1992;14:419-47.

33 Bohe J, Low A, Wolfe RR, et al. Human muscle protein synthesis is modulated by extracellular, not intramuscular, amino acid availability: a dose-response study. J Physiol 2003;552(Pt 1):315-24.

$34 \mathrm{Ha} \mathrm{E}$, Zemel MB. Functional properties of whey, whey components, and essential amino acids: mechanisms underlying health benefits for active people [review]. J Nutr Biochem 2003;14:251-8.

35 Morifuji M, Sakai K, Sanbongi C, et al. Dietary whey protein downregulates fatty acid synthesis in the liver, but upregulates it in skeletal muscle of exercisetrained rats. Nutrition 2005;21:1052-8.

36 Morifuji M, Sakai K, Sanbongi C, et al. Dietary whey protein increases liver and skeletal muscle glycogen levels in exercise-trained rats. Br J Nutr 2005;93:439-45.

37 Marshall K. Therapeutic applications of whey protein. Altern Med Rev 2004:9:136-56.

38 Yalcin AS. Emerging therapeutic potential of whey proteins and peptides. Curr Pharm Des 2006;12:1637-43.

39 Lands LC, Grey VL, Smountas AA. Effect of supplementation with a cysteine donor on muscular performance. J Appl Physiol 1999;87:1381-5.

40 Kalman DS. Gelatin. In: Wolinsky I, Driskell JA, eds. Nutritional ergogenic aids. Boca Raton, FL: CRC Press, 2004:105-13.

41 Moskowitz RW. Role of collagen hydrolysate in bone and joint diseases. Semin Arthritis Rheum 2000;30:87-9.

42 Horiguchi N, Horiguchi $\mathrm{H}$, Suzuki Y. Effect of wheat gluten hydrolysate on the immune system in healthy human subjects. Biosci Biotechnol Biochem 2005:69:2445-9.

43 Castell LM, Newsholme EA. The effects of oral glutamine supplementation on athletes after prolonged, exhaustive exercise. Nutrition 1997;13:738-42.

44 Calbet JA, MacLean DA. Plasma glucagon and insulin responses depend on the rate of appearance of amino acids after ingestion of different protein solutions in humans. J Nutr 2002;132:2174-82.

45 Calbet JA, Holst JJ. Gastric emptying, gastric secretion and enterogastrone response after administration of milk proteins or their peptide hydrolysates in humans. Eur J Nutr 2004;43:127-39.

46 Ivy JL, Goforth HW Jr, Damon BM, et al. Early postexercise muscle glycogen recovery is enhanced with a carbohydrate-protein supplement. J Appl Physiol 2002;93:1337-44.

47 Zawadzki KM, Yaspelkis BB III, Ivy JL. Carbohydrate-protein complex increases the rate of muscle glycogen storage after exercise. J Appl Physiol 1992;72:1854-1859.

48 Crowe MJ, Weatherson JN, Bowdeen BF. Effects of dietary leucine supplementation on exercise performance. Eur J Appl Physiol 2005;29:1-9. 
49 Coburn JW, Housh DJ, Housh TJ, et al. Effects of leucine and whey protein supplementation during eight weeks of unilateral resistance training. J Strength Cond Res 2006;20:284-91.

50 Bird SP, Tarenning KM, Marino FE. Independent and combined effects of liquid carbohydrate/essential amino acid ingestion on hormonal and muscular adaptations following resistance training in untrained men. Eur J Appl Physiol 2006;97:225-38.

51 Volek JS. Influence of nutrition on responses to resistance training. Med Sci Sports Exerc 2004;36:689-96.

52 Kraemer WJ, Ratamess NA. Hormonal responses and adaptations to resistance exercise and training. Sports Med 2005;35:339-61.

53 Crewther B, Keogh J, Cronin J, et al. Possible stimuli for strength and power adaptation: acute hormonal responses. Sports Med 2006;36:215-38.

54 Manninen AH. High-protein diets and purported adverse effects: where is the evidence? Sports Nutr Rev J 2004;1:45-51.

55 Martin WF, Armstrong LE, Rodriguez NR. Dietary protein intake and renal function. Nutr Metab (Lond) 2005;2:25.

56 Martin WF, Cerundolo LH, Pikosky MA, et al. Effects of dietary protein intake on indexes of hydration. J Am Diet Assoc 2006; 106:587-9.

57 Heaney RP. Protein intake and bone health: the influence of belief systems on the conduct of nutritional science. Am J Clin Nutr 2001;73:5-6.

58 Bonjour JP. Dietary protein: an essential nutrient for bone health. J Am Coll Nutr 2005;24:526S-36S.

59 Mullins NM, Sinning WE. Effects of resistance training and protein supplementation on bone turnover in young adult women. Nutr Metab (Lond) 2005;2:19

60 Ballard TL, Clapper JA, Speckler BL, et al. Effect of protein supplementation during a 6-mo strength and conditioning program on insulin-like growth factor I and markers of bone turnover in young adults. Am J Clin Nutr 2005;81:1442-8

61 Booth F. The many flavors of IGF-I. J Appl Physiol 2006;100:1755-6.

62 Tipton KD, Wolfe RR. Protein and amino acids for athletes. J Sports Sci 2004;22:65-79.

63 Lemon PW. Beyond the zone: protein needs of active individuals. J Am Coll Nutr 2000;19:513S-521S.

64 Phillips SM. Protein requirements and supplementation in strength sports. Nutrition 2004;20:689-95.

65 Wilson J, Wilson GJ. Contemporary issues in protein requirements and consumption for resistance trained athletes. J Int Soc Sports Nutr 2006:3:7-27.
66 Halton TL, Hu FB. The effects of high protein diets on thermogenesis, satiety and weight loss: a critical review. J Am Coll Nutr 2004;23:373-85.

67 Lejeune MP, Kovacs MB, Westerterp-Plantenga MP. Additional protein intake limits weight regain after weight loss in humans. Br J Nutr 2005;93:281-9.

68 Layman DK, Evans E, Baum JL, et al. Dietary protein and exercise have additive effects on body composition during weight loss in adult women. J Nutr 2005; 135:1903-10.

69 Lowery L, Forsythe CE. Protein and overtraining: potential applications for free-living athletes. J Int Soc Sports Nutr 2006:3:42-50.

70 Antonio J, Manninen AH. Eating to improve body composition. In: Antonio J, Kalman D, Stout J, et al, eds. Essentials of sports nutrition and supplements. Totowa, NJ: Humana Press, 2006; in press.

71 Flakoll PJ, Judy T, Flinn K, et al. Postexercise protein supplementation improves health and muscle soreness during basic military training in Marine recruits. J Appl Physiol 2004;96:951-6.

72 Borer KT. Hormonal regulation of fuel use in exercise. In: Exercise endocrinology. Champaign, IL: Human Kinetics, 2003:97-120.

73 Volek JS, Sharman RJ, Love DM, et al. Body composition and hormonal responses to a carbohydrate-restricted diet. Metabolism 2002;51:864-70.

74 Carlson MG, Campbell PJ. Intensive insulin therapy and weight gain in IDDM. Diabetes 1993;42:1700-7.

75 Borghouts LB, Keizer HA. Exercise and insulin sensitivity: a review. Int J Sports Med 2000;21:1-12.

76 Ruderman NB, Park H, Kaushik VK, et al. AMPK as a metabolic switch in rat muscle, liver and adipose tissue after exercise. Acta Physiol Scand 2003; 178:435-42.

77 Krzentowski G, Pirnay F, Luyckx AS, et al. Metabolic adaptations in postexercise recovery. Clin Physiol 1982;2:277-88.

78 Folch N, Peronnet F, Massicotte D, et al. Metabolic response to small and large ${ }^{13} \mathrm{C}$-labelled pasta meals following rest or exercise in man. Br J Nutr 2001;85:671-80.

79 Zierath JR, Hawley JA, Dyck DJ, et al. Energy turnover and substrate utilization. In: Mooren FC, Völker K, eds. Molecular and cellular exercise physiology. Champaign, IL: Human Kinetics, 2005:145-78.

80 Dandona P, Mohanty P, Chaudhuri A, et al. Insulin infusion in acute illness. J Clin Invest 2005;1 15:2069-72.

81 MacIntyre DL, Reid WD, McKenzie DC. Delayed muscle soreness. The inflammatory response to muscle injury and its clinical implications. Sports Med 1995;20:24-40

$82 \mathrm{Ji}$ LL. Antioxidants and oxidative stress in exercise. Proc Soc Exp Biol Med 1999;222:283-92.

\section{$\mathrm{ECHO}$}

\section{Dangers of skimboarding}

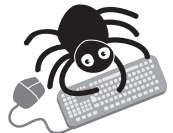

Please visit the British Journal of Sports Medicine website [www. bisportmed. com] for a link to the full text of this article.
- kimboarding is an increasingly popular water sport similar to surfing. As a wave recedes, a round wooden disc is thrown into shallow water. The participant runs and jumps onto the disc to try to ride this board along the beach or into the surf. Unfortunately the learning curve is steep. Protective equipment is not usually worn. There is little tuition and the potential dangers are not widely understood.

Over a 5 month period-May to September 2003-10 patients were seen by the fracture team at the Royal Cornwall Hospitals NHS Trust. Of the 10, eight were male, with an average age 18.7 (range 12-31).

There was an equal incidence of left and right sided injuries. All the injuries were closed with no neurovascular symptoms or signs. Eight were to the lower limb, all of which were fractures of the distal tibia, ankle, and mid-foot. Six patients required hospital admission with eight operations performed.

Skimboarding is associated with frequent falls and injuries, similar to those sustained in skating, rollerblading, and skateboarding. However, while the most common injuries from these sports are to the wrist (33\%), the skimboarding injuries recorded in this study were predominantly to the lower limb, reflecting the fact that these are usually high energy torsional falls. A multitude of soft tissue injuries from skimboarding were seen by the hospital's A\&E department in the same period. The authors think there should be a warning on the boards at point of sale, indicating the high risk of injury.

A Williams MR, et al. Emergency Medicine Journal 2006;23:137 